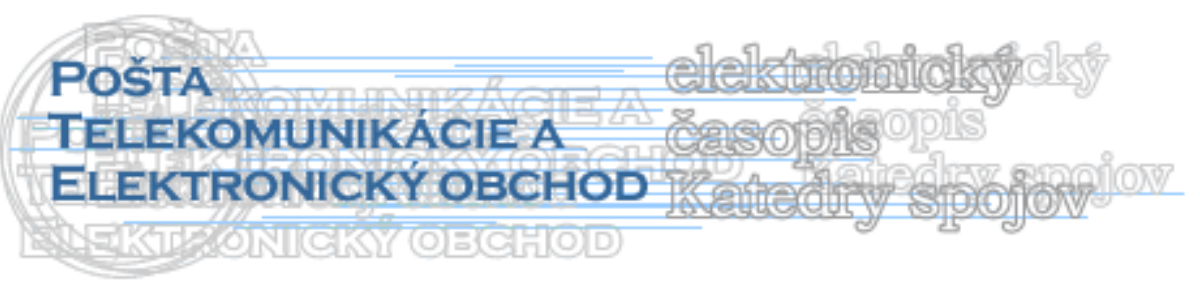

\title{
POSKYTOVANIE INTERNETOVÝCH SLUŽIEB MALÝM FIRMÁM V LOKALITE ŽILINA
}

\author{
Margita Majerčáková*
}

\section{Úvod}

Zvyšujúce sa nároky užívatel'ov na používanie internetu vedú $\mathrm{k}$ neustálemu napredovaniu nových technológií, ktoré nahrádzajú staršie technológie s nižšími prenosovými rýchlost’ami. Internetové služby sa stávajú čoraz viac dostupnými. Problémom však zostáva výber vhodnej použitej technológie a vol'ba poskytovatel'a, existuje totiž viacero technológií a množstvo poskytovatel'ov. Nie je jednoduché sa preto správne rozhodnút'.

\section{Prehl'ad technológií}

$\mathrm{Na}$ Slovensku existuje množstvo firiem, ktoré poskytujú služby pripojenia k internetu. Poskytovatelia internetových služieb (ISP- Internet Service Provider) majú vybudovanú siet's prípojnými miestami v rámci svojho územia. Užívatel'ovi sú tak poskytované prípojné miesta (body), ktorých počet závisí od vel'kosti siete samotného poskytovatel'a. Aby poskytovatel' internetových služieb mohol užívatel'ov pripojit' k internetu, musí byt' sám pripojený. Hlavní provideri s väčšími siet’ami sú do internetu pripojení zahraničnou vysokorýchlostnou dátovou linkou. Dôležitá je taktiež možnost' zvyšovania kapacity tejto linky aby s rastúcim počtom užívatel'ov bola zabezpečená rovnaká kvalita ponúkaných služieb. Množstvo firiem na Slovensku poskytuje prístup do siete internet cez jedného z hlavných providerov, nakol'ko vlastnú dátovú linku do zahraničia nevlastnia.

V súčasnosti existuje niekol'ko rôznych spôsobov poskytovania internetových služieb . Všetky spôsoby poskytovania internetových služieb poslednou míl'ou je možné rozdelit' do dvoch vel'kých skupín podl'a druhu použitej technológie:

- internetové služby prostredníctvom káblových vedení

- metalickými vedeniami,

- optickými vedeniami,

- bezdrôtové internetové služby

- fixné

- mobilné.

Tieto dve vel'ké skupiny možno d'alej rozdelit':

Internetové služby metalickými káblovými vedeniami:

- Dial-up

- ISDN

- ADSL

- Káblové pripojenie (CATV)

- Technológia DPL (Digital Power Line)

\footnotetext{
* Dr. Ing. Margita Majerčáková, Katedra spojov, Fakulta prevádzky a ekonomiky dopravy a spojov, Žilinská univerzita v Žiline, Univerzitná 1, 01026 Žilina, Slovenská republika, tel.: +421415133126, fax:

+421415655615 e-mail: Margita.Majercakova@fpedas.utc.sk
} 
Internetové služby optickými káblovými vedeniami

- FTTH (Fiber To The Home)

- FTTO (Fiber To The Office)

Bezdrôtové fixné internetové služby

- Wi-Fi (Wireless Fidelity)

- FWA (Fixed Wireless Access)

- Satelitné pripojenie VSAT

Bezdrôtové mobilné internetové služby

- HSCSD (High Speed Circuit Switched Data)

- GPRS (General Packet Radio Service)

- EDGE (Enhanced Data for GSM Evolution)

- FLASH-OFDM (Fast Low-latency Access with Seamless Handoff - Ortogonal Frequency Division Multiplexing)

- UMTS FDD (Universal Mobile Telecommunication System Frequency Division Duplex)

\section{Analýza trhu a porovnanie internetových služieb v Žiline}

Za posledné roky nastal neočakávaný nárast $\mathrm{v}$ počte užívatel'ov využívajúcich internetové služby [1]. Trh poskytovania internetových služieb sa neustále rozrastá a vzniká tak čoraz väčšia konkurencia. Na poskytovanie týchto služieb musí mat' provider povolenie udelené Telekomunikačným úradom Slovenskej republiky. Neustále narastajúce nároky užívatel'ov internetových služieb [2] spôsobujú, že o technológie prostredníctvom káblových vedení ako dial-up, ISDN a bezdrôtových pripojení prostredníctvom technológií HSCSD, GPRS nie je záujem. Trendom je rýchlejšie a kvalitnejšie pripojenie s väčším rozsahom poskytovaných služieb, ktoré prinášajú novšie technológie. Do našej analýzy boli zahrnuté technológie: ADSL, káblové pripojenie (CATV), Wi-Fi, WiMAX, FWA, satelitné pripojenie, EDGE, FLASH-OFDM a UMTS FDD [3]. Výsledky analýzy sú uvedené v tab. 1. V meste Žilina poskytuje internetové služby celkom 31 providerov. Najväčšie zastúpenie má poskytovanie internetových služieb prostredníctvom technológie ADSL, za ňou nasleduje bezdrôtová technológia Wi-Fi. Technológie sú najrozšírenejšie a taktiež najdostupnejšie z pohl'adu rýchlosti, cien na potrebné zariadenia, cien mesačných programov a pokrytia.

Najrýchlejší dátový prenos $\mathrm{z}$ uvedených technológií poslednou mílou $\mathrm{k}$ užívatel'ovi umožňuje bezdrôtová technológia FWA $26 \mathrm{GHz}$, ktorá poskytuje dátový prenos rýchlost'ou až do $34 \mathrm{Mbit} / \mathrm{s}$. Vzhl'adom však na ceny za prenosové rýchlosti, poskytované služby a potrebné vybavenie sa tak stáva málo dostupnou i pre malé firmy. Z prehl'adu technológií a ich poskytovaných dátových programov možno vidiet', že jednoznačne najlacnejšou vol'bou pripojenia do internetu bez viazanosti je Wi-Fi. Jej pomerne nízke náklady na zriadenie a mesačné dátové programy konkurujú aj pripojeniam ADSL. Ponúkané prenosové rýchlosti u Wi-Fi začínajú už od $128 \mathrm{kbit} / \mathrm{s}$, čo už je v dnešnej dobe vzhl'adom na nároky užívatel'a nepostačujúce, avšak maximálne prenosové rýchlosti sú $1 \mathrm{Mbit} / \mathrm{s}$. vel'kou výhodou tejto technológie je symetrický prenos dát. ADSL technológia je najrozšírenejšou technológiou, nakol'ko sa poskytuje na existujúcom telefónnom vedení, jej dostupnost' je však obmedzená. Poskytovatelia Wi-Fi technológie sa väčšmi zameriavajú na lokalilty, ktoré nie sú dostupné ADSL technológiou. Wi-Fi sa môže javit' ako nepostačujúca technológia pre ponúkané prenosové rýchlosti, nakol'ko ADSL už max. prenosovú rýchlost' Wi-Fi poskytuje už vo svojich základných dátových programoch. Wi-Fi prenosové rýchlosti je možné zvýšit' nad ponúkaný $1 \mathrm{Mbit} / \mathrm{s}$, avšak $\mathrm{z}$ hl'adiska providerov nie je to efektívne. S prenosovou rýchlost'ou sa znižuje vzdialenost' na akú je technológia schopná prenos uskutočnit' a to prináša so sebou pokrytie lokalít väčším počtom prístupových bodov (Access Pointov). 


\begin{tabular}{|c|c|c|c|c|c|c|c|c|c|}
\hline & \multicolumn{9}{|c|}{ Druh použitej technológie } \\
\hline & ADSL & CATV & Wi-Fi & WiMAX & \begin{tabular}{|ll} 
FWA & 26 \\
GHz & \\
\end{tabular} & $\begin{array}{l}\text { Satelitné } \\
\text { pripojenie }\end{array}$ & $\overline{\text { EDGE }}$ & $\begin{array}{l}\text { FLASH } \\
\text { OFDM }\end{array}$ & $\begin{array}{l}\text { UMTS } \\
\text { FDD }\end{array}$ \\
\hline $\begin{array}{l}\text { Spôsob } \\
\text { prenosu dát }\end{array}$ & asymet. & asymet. & symet. & symet. & symet. & asymet. & asymet. & asymet. & asymet. \\
\hline $\begin{array}{l}\text { Priemerná } \\
\text { latencia }\end{array}$ & $20 \mathrm{~ms}$ & $20 \mathrm{~ms}$ & $20 \mathrm{~ms}$ & $40 \mathrm{~ms}$ & $50 \mathrm{~ms}$ & $800 \mathrm{~ms}$ & $700 \mathrm{~ms}$ & $50 \mathrm{~ms}$ & $300 \mathrm{~ms}$ \\
\hline $\begin{array}{l}\text { Max.rýchlost' } \\
\text { u ISP }\end{array}$ & $\begin{array}{l}2560 \\
\text { kbit/s } \\
384 \mathrm{kbit} / \mathrm{s}\end{array}$ & $\begin{array}{ll}6 & \mathrm{Mbit} / \mathrm{s} \\
1 & \mathrm{Mbit} / \mathrm{s}\end{array}$ & $\begin{array}{ll}1 & \mathrm{Mbit} / \mathrm{s} \\
1 \mathrm{Mbit} / \mathrm{s}\end{array}$ & $\begin{array}{l}2 \mathrm{Mbit} / \mathrm{s} \\
2 \mathrm{Mbit} / \mathrm{s}\end{array}$ & $\begin{array}{l}34 \mathrm{Mbit} / \mathrm{s} \\
34 \mathrm{Mbit} / \mathrm{s}\end{array}$ & $\begin{array}{l}2048 \mathrm{kbit} / \mathrm{s} \\
128 \mathrm{kbit} / \mathrm{s}\end{array}$ & $\begin{array}{l}237 \\
\text { kbit/s } \\
118 \\
\text { kbit/s }\end{array}$ & $\begin{array}{l}2048 \\
\text { kbit/s } \\
512 \\
\text { kbit/s }\end{array}$ & $\begin{array}{l}384 \\
\mathrm{kbit} / \mathrm{s} \\
64 \mathrm{kbit} / \mathrm{s}\end{array}$ \\
\hline $\begin{array}{l}\text { Max.rýchlost' } \\
\text { technológiou }\end{array}$ & $\begin{array}{l}8 \mathrm{Mbit} / \mathrm{s} \\
1,5 \\
\text { Mbit/s }\end{array}$ & $\begin{array}{l}42 \mathrm{Mbit} / \mathrm{s} \\
10 \mathrm{Mbit} / \mathrm{s}\end{array}$ & $\begin{array}{lll}1 & \mathrm{Mbit} / \mathrm{s} \\
1 & 1 & \mathrm{Mbit} / \mathrm{s}\end{array}$ & $\begin{array}{l}75 \mathrm{Mbit} / \mathrm{s} \\
75 \mathrm{Mbit}\end{array}$ & $\begin{array}{l}134 \\
\text { Mbit/s } \\
134 \\
\text { Mbit/s }\end{array}$ & $\begin{array}{l}10 \mathrm{Mbit} / \mathrm{s} \\
2 \mathrm{Mbit} / \mathrm{s}\end{array}$ & $\begin{array}{l}237 \\
\text { kbit/s } \\
118 \\
\text { kbit/s }\end{array}$ & $\begin{array}{l}2 \mathrm{Mbit} / \mathrm{s} \\
0,9 \\
\mathrm{Mbit} / \mathrm{s}\end{array}$ & $\begin{array}{l}2 \mathrm{Mbit} / \mathrm{s} \\
2 \mathrm{Mbit} / \mathrm{s}\end{array}$ \\
\hline $\begin{array}{l}\text { Pokrytie } \\
\text { v Žiline }\end{array}$ & lokality & lokality & cca $100 \%$ & $100 \%$ & $100 \%$ & $100 \%$ & $100 \%$ & $100 \%$ & $100 \%$ \\
\hline $\begin{array}{l}\text { Cena } \\
\text { za zariadenia } \\
\text { s DPH }\end{array}$ & min. & $2500 \mathrm{Sk}$ & min. & $18950 \mathrm{Sk}$ & $17000 \mathrm{Sk}$ & $78000 \mathrm{Sk}$ & min. & $\begin{array}{|ll|}\text { min. } & \\
10 & 000 \\
\text { Sk } & \\
\end{array}$ & $\begin{array}{ll}\min . & \\
11 & 500 \\
\text { Sk } & \end{array}$ \\
\hline \begin{tabular}{|l|} 
Počet ISP V \\
Žiline
\end{tabular} & 9 & 1 & 7 & 3 & 4 & 3 & 2 & 1 & 1 \\
\hline $\begin{array}{l}\text { Casová } \\
\text { viazanost' } \\
\end{array}$ & $0,12,24 \mathrm{~m}$ & $0,13,15 \mathrm{~m}$ & $\begin{array}{l}0,12,18,24 \\
\mathrm{~m}\end{array}$ & $0,12,24 \mathrm{~m}$ & dohodou & $0 \mathrm{~m}$ & $\begin{array}{l}0,12,24 \\
\mathrm{~m}\end{array}$ & $0,24 \mathrm{~m}$ & $0,24 \mathrm{~m}$ \\
\hline $\begin{array}{l}\text { Najlacnejší } \\
\text { ISP }\end{array}$ & $\begin{array}{l}\text { Slovak } \\
\text { Telekom }\end{array}$ & \begin{tabular}{|l|} 
UPC \\
Slovensko
\end{tabular} & Gaya & - & $?$ & $\begin{array}{l}\text { Slovenské } \\
\text { rádiokomun. }\end{array}$ & $\begin{array}{l}\text { T- } \\
\text { Mobile }\end{array}$ & T-Mobile & Orange \\
\hline $\begin{array}{l}\text { Min. } \\
\text { poplatok } \\
\text { s DPH } \\
\end{array}$ & 743 Sk & 799 Sk & 237 Sk & nie je & $\begin{array}{l}\text { cca } \\
8000 \text { Sk }\end{array}$ & $7120 \mathrm{Sk}$ & $702 \mathrm{Sk}$ & $713 \mathrm{Sk}$ & $951 \mathrm{Sk}$ \\
\hline $\begin{array}{l}\text { Prenosová } \\
\text { rýchlost' }\end{array}$ & $\begin{array}{l}1024 \\
\mathrm{kbit} / \mathrm{s} \\
256 \mathrm{kbit} / \mathrm{s}\end{array}$ & $\begin{array}{l}512 \mathrm{kbit} / \mathrm{s} \\
128 \mathrm{kbit} / \mathrm{s}\end{array}$ & $128 \mathrm{kbit} / \mathrm{s}$ & - & $256 \mathrm{kbit} / \mathrm{s}$ & $\begin{array}{l}512 \mathrm{kbit} / \mathrm{s} \\
64 \mathrm{kbit} / \mathrm{s}\end{array}$ & $\begin{array}{l}237 \\
\text { kbit/s } \\
118 \\
\text { kbit/s }\end{array}$ & $\begin{array}{l}1024 \\
\text { kbit/s } \\
256 \\
\text { kbit/s }\end{array}$ & $\begin{array}{l}384 \\
\mathrm{kbit} / \mathrm{s} \\
64 \mathrm{kbit} / \mathrm{s}\end{array}$ \\
\hline $\begin{array}{l}\text { Dátové } \\
\text { obmedzenie }\end{array}$ & $600 \mathrm{MB}$ & nie & nie & - & nie & nie & $700 \mathrm{MB}$ & $2000 \mathrm{MB}$ & $\begin{array}{l}2000 \\
\mathrm{MB}\end{array}$ \\
\hline $\begin{array}{l}\text { Časové } \\
\text { obmedzenie }\end{array}$ & nie & nie & nie & - & nie & nie & nie & nie & nie \\
\hline
\end{tabular}

Tab. 1 Analýza internetových služieb v Žiline

Za novú zaujímavú technológiu možno považovat' bezdrôtovú fixnú technológiu FWA - WiMAX poskytujúcu symetrickú prenosovú rýchlost' dátových programoch až do $2 \mathrm{Mbit} / \mathrm{s}$. Teoreticky je schopná prenosových rýchlosti až do $75 \mathrm{Mbit} / \mathrm{s}$. WiMAX sa stáva konkurentom káblových sietí a digitálnych prípojok ADSL a to nielen v nedotknutých oblastiach, ale aj v centrách miest, nakol'ko nie je potrebná priama viditel'nost' medzi prijímačom a základňovou stanicou a umožňuje prenos do vzdialenosti $15 \mathrm{~km}$.

Za najnovšiu technológiu na Slovenskú možno považovat' mobilnú bezdrôtovú technológiu UMTS FDD, ktorá sa snaží presadit' práve vd'aka svojej mobilite. Ponúka prenosové rýchlosti $384 \mathrm{kbit} / \mathrm{s}$ pre dowstream, do budúcna sa však uvažuje o jej vylepšeniach a nadstavbách, ktoré majú priniest' prenosové rýchlosti konkurujúce dnešnému káblovému pripojeniu alebo ADSL technológií. 


\section{Záver}

Trh poskytovaných internetových služieb v lokalite Žilina je značne rozvinutý. Dôležitým faktorom pri vol'be poskytovatel'a a služieb ostáva spol'ahlivost' a kvalita, cena u niektorých nemusí byt' preto vždy rozhodujúca. Je teda na firme samotnej, pre ktorého poskytovatel'a a internetové služby sa rozhodne. Budúcnost' so sebou určite prinesie nové technológie, progresívnejšie, cenovo dostupnejšie a s vyššou prenosovou rýchlost'ou. Zväčší sa rozsah pokrytia, metalické vedenia nahradia optické, rozšíria sa možnosti mobilného internetu.

\section{Literatúra}

[1] VACULÍK, J.: Telematické služby - Žilina : Žilinská univerzita v EDIS, 1998. - 127 s., ISBN 80-7100-530-4.

[2] MADLEŇÁK, R. Elektronický obchod. Žilina: Žilinská univerzita, 2004, 160 s. ISBN 80-8070-192-X.

[3] BUŠÍK, M.: Poskytovanie internetových služieb v segmente malých firiem, Diplomová práca, ŽU v Žiline, 2006, 107 str.

\section{Grantová podpora}

I14-07-140 Príležitosti a hrozby e-mailovej komunikácie

VEGA 1/2548/05 Kvalita služieb vnímaná zákazníkom 